\title{
Expressional studies of microRNAs in Hepatitis B Patients of Quetta, Pakistan
}

\author{
Shah Jahan ${ }^{1}$, Muhammad Younas Khan Barozai ${ }^{*}$, Muhammad Din ${ }^{2}$, \\ Habibullah Achakzai ${ }^{2}$ and Ashif Sajjad ${ }^{1}$ \\ 1. Institute of Biochemistry, University of Balochistan Quetta-Pakistan \\ 2. Department of Botany University of Balochistan Quetta-Pakistan \\ *Corresponding author's email: barozaikhan@ gmail.com \\ Citation \\ Shah Jahan, Muhammad Younas Khan Barozai, Muhammad Din, Habibullah Achakzai and Ashif Sajjad. \\ Expressional studies of microRNAs in Hepatitis B Patients of Quetta, Pakistan. Pure and Applied Biology. Vol. 6,
} Issue 3, pp1044-1052. http://dx.doi.org/10.19045/bspab.2017.600111

\begin{tabular}{llll}
\hline \hline Received: 07/07/2017 & Revised: 17/08/2017 & Accepted: 30/08/2017 & Online First: 05/09/2017 \\
\hline \hline
\end{tabular}

\section{Abstract}

Hepatitis B (HB) is a severe and widespread infectious liver disease affecting millions of people throughout the globe and caused by hepatitis B virus (HBV). Persistent HBV infections results severe pathologies which include development of chronic hepatic insufficiency, cirrhosis, and hepatocellular carcinoma (HCC). In response of the $\mathrm{HBV}$, patient cells show differential expression of microRNAs (miRNAs) to manage and fight the HB. miRNAs are small, endogenous and regulatory RNAs, that play an important role in post-transcriptional gene regulation. The aim of this research is to study the expressional pattern of fifteen miRNAs; hsa mir-20, 21, 30, 99, 122, 141, 190, 200, 223, 320, 574, 1228, 4532, 6127 and 6852 in hepatitis B patients of Quetta, Pakistan, selected through literature survey on the basis of their significant role in hepatitis. Briefly, the total RNA from the hepatitis B patient of Quetta, Pakistan and healthy person extracted and subjected to the stem-loop RT-PCR (reverse transcriptional-PCR) for the selected fifteen miRNAs and GAPDH-as internal control gene. The eight miRNAs; hsamir-20, 21, 30, 99, 141, 574, 4532 and 6852 showed upregulation, whereas, the six miRNAs; hsa-mir-122, 190, 200, 223, 320, and 6127 showed down-regulation in HB-patient. One miRNA; 1228 is observed with equal expression in both patient and healthy person. Hepatitis responding miRNAs would be useful to better understand the disease for early diagnose and cure.

Keywords: HBV; microRNAs; RT-PCR

\section{Introduction}

MicroRNAs (miRNAs) with other tiny RNAs such as; short interfering RNAs (siRNAs) constitute an important regulatory class of RNA, called as, small RNAs. The miRNAs are non-coding, endogenously expressed by cells with length ranges between 18 to 26 nucleotides (nts) and involve in post-transcriptional gene regulation [1]. In human, 30\% of the whole gene set regulation by miRNAs, is the evidence of its significance for the maintaining of life [2]. The miRNAs have been reported to be produced cell and tissue specific, indicating temporal phases expression and as well as role in several biological processes, such as development, differentiation, proliferation, response to biotic and abiotic stresses and the establishment of pathological states [2-5].

Hepatitis B (HB) is an infectious liver damaging disease and its main reason is the 
hepatitis B virus (HBV). HBV on the basis of the genome is a DNA virus with 3.2 kilobases size and has a relaxed-circular and closed architecture with four gene capacity. These are $\mathrm{S}$, Core, $\mathrm{P}$ and $\mathrm{X}$ genes and involved in the coding of an envelope, a core with e, reverse transcriptase with DNA polymerase and X-proteins respectively [6]. After the invasion in the liver cells, HBV relaxed-circular DNA reshaped itself and transcribed into viral messenger RNAs and can cause both acute and chronic disease [6, 7]. HB initially with no indications or symptoms, later show the symptoms as; jaundice, fatigue, blackish urine color, abdominal pain, nausea and illness and if not cured may cause death within few weeks [8]. Chronic HB has affected more than 350 million people worldwide and thus cause a serious threat to public health. The majority, $75 \%$ of 350 million people are from South East Asia and the Western Pacific region. This is clearly showing that why countries like Pakistan should pay more attention for research and awareness for the HB.

The alteration in the expression of specific miRNAs to respond the viral invasion by the host cell is one of the prime areas of today gene regulation research. These studies on the relationship between miRNAs and human hepatitis B virus (HBV) infection; have produced convincing evidence that the interplay between $\mathrm{HBV}$ and cellular miRNAs is important to many facets of HBV replication and pathogenesis [9]. The present research is aimed to study and understand the expressional response of the significant selected miRNAs in the $\mathrm{HB}$ patients of Quetta, Pakistan.

\section{Materials and methods}

\section{Identification of the significant $\mathrm{HBV}$ responding miRNAs}

To identify the vital and significant miRNAs demonstrating a strong expressional response to $\mathrm{HBV}$, a detail literature survey is done. Finally fifteen (15) miRNAs; hsa-mir-
20, 21, 30, 99, 122, 141, 190, 200, 223, 320, $574,1228,4532,6127$ and 6852 were identified as most responsive miRNAs [1012] and the Glyceraldehyde 3-phosphate dehydrogenase (GADPH) as internal control [13]. Stem-loop primers as shown in Tabel 1, for the selected 15 miRNAs were designed by using bioinformatics tool "Primer3" publically available at http://bioinfo.ut.ee/primer3-0.4.0/.

\section{Blood sampling}

Total six blood (serum) samples of the HB patients, three male and three female, diagnosed by experienced pathologists for HBV and showing the positive test for Hepatitis B surface antigen (HBsAgpositive) were collected from outdoor patients of Al-Shafi hospital, Quetta, Balochistan- Pakistan. Their ages were ranged from 30-50 years. The control (healthy) blood sampling is done from the healthy, non-HB and HBV negative volunteer students and scholars of the Department of Botany, University of Balochistan Quetta. All the blood samples, in anticoagulant tubes, were stored at $-20^{\circ} \mathrm{C}$ in the freezer of Molecular Biology and Bioinformatics Lab (MBBL) of the Department of Botany, University of Balochistan Quetta.

\section{RNA extraction and cDNA synthesis}

Total RNAs from the blood (serum) samples of Hepatitis B patient and volunteer healthy persons were extracted by the Trizol method. Briefly, $1 \mathrm{ml}$ Trizol is added to a $1.5 \mathrm{ml}$ tube containing $0.4 \mathrm{ml}$ of the sample, vortex for 20-30 second and incubated on ice for 15 minutes. The tubes were centrifuged at $13000 \mathrm{~g}$ for 10 minutes at $4^{\circ} \mathrm{C}$. The supernatant was extracted first with an equal volume of Chloroform Isoamyl alcohol (CI) (24:1, v/v) and secondly with an equal volume of Phenol Chloroform Isoamyl (PCI) $(25: 24: 1 \mathrm{v} / \mathrm{v} / \mathrm{v})$. The total RNA was precipitated from the upper aqueous layer by twice volume of the $100 \%$ 
ice chilled Ethanol. The RNA pellet was dissolved in $40 \mu \mathrm{l}$ DEPC treated water and stored at -20 0C. Quantitative and qualitative analyses of RNAs were performed by measuring optical density at $260 \mathrm{~nm}$ and $280 \mathrm{~nm}$ using Genova Nano spectrophotometer. Total RNAs integrity were checked by loading and running on a
$1 \%$ agarose gel and visualized under UV light for ribosomal RNA bands. The cDNAs from the $1 \mu \mathrm{g} \mathrm{HB}$ patient and control total RNAs were synthesized by using the Thermo Scientific ${ }^{\mathrm{TM}}$ RevertAid $^{\mathrm{TM}} \mathrm{H}$ Minus First Strand cDNA Synthesis Kit, according to supplier's protocol.

Tabel 1. The fifteen human selected miRNAs' primers for RT-PCR expression analysis in hepatitis B patients from Quetta, Pakistan. The fifteen human significant miRNAs demonstrating strong expressional response to $\mathrm{HBV}$, identified through literature survey, were subjected to expression analysis through RT-PCR. The selected miRNAs, their primers, TM (melting temperature) and the product size (in base pair, bp) are shown here

\begin{tabular}{|c|c|c|c|}
\hline miRNA & Primers & TM & Product size \\
\hline hsa-mir-20 & $\begin{array}{c}\text { TGCCTGGTCTATCTGATGTGA } \\
\text { ACAGTTTGATTGGGCGACA }\end{array}$ & $\begin{array}{l}59.26 \\
60.10\end{array}$ & 117 \\
\hline hsa-mir-21 & $\begin{array}{c}\text { TGTTTTGCCTACCATCGTGA } \\
\text { TGGATATGGATGGTCAGATGA }\end{array}$ & $\begin{array}{l}60.11 \\
60.16\end{array}$ & 111 \\
\hline hsa-mir-30 & $\begin{array}{l}\text { TGGATTAGCAAGCCCTCTGT } \\
\text { CGCTGTAAACATCCGACTGA }\end{array}$ & $\begin{array}{l}59.84 \\
59.86\end{array}$ & 210 \\
\hline hsa-mir-99 & $\begin{array}{l}\text { CTGGACTCCTGGGTTCCTT } \\
\text { GACACGGACCCACAGACAC }\end{array}$ & $\begin{array}{l}59.09 \\
59.99\end{array}$ & 154 \\
\hline hsa-mir-122 & $\begin{array}{c}\text { TCCCCTTGTCTCCTTGTCC } \\
\text { TTCCAGCCCTGGTGTACTCT }\end{array}$ & $\begin{array}{l}60.03 \\
59.72 \\
\end{array}$ & 134 \\
\hline hsa-mir-141 & $\begin{array}{c}\text { CCCTGTAGCAACTGGTGAGC } \\
\text { CCAGACAGTGTTAGGAGCTTCA }\end{array}$ & $\begin{array}{l}60.85 \\
59.54\end{array}$ & 110 \\
\hline hsa-mir-190 & $\begin{array}{l}\text { CTTTGCAACTGGAAGGAAGG } \\
\text { ATGAAAGAGGGTGGTGCTGA }\end{array}$ & $\begin{array}{l}59.85 \\
60.66\end{array}$ & 150 \\
\hline hsa-mir-200 & $\begin{array}{l}\text { TACTGAGCTTCCCAGCGAGT } \\
\text { ACCTGACTCCATCCAATGCT }\end{array}$ & $\begin{array}{l}60.16 \\
59.54\end{array}$ & 180 \\
\hline hsa-mir-223 & $\begin{array}{l}\text { GGAATCAGAGTCCCCTCCAT } \\
\text { CATGGAGTGTCCAACTCAGC }\end{array}$ & $\begin{array}{l}60.28 \\
59.26\end{array}$ & 150 \\
\hline hsa-mir-320 & $\begin{array}{l}\text { GTCACAACCTCACCTGCAAC } \\
\text { CGCCGCCTGATAAATACTGT }\end{array}$ & $\begin{array}{l}59.16 \\
60.12\end{array}$ & 154 \\
\hline hsa-mir-574 & $\begin{array}{l}\text { ATCAGCCCCAAACCTATGTG } \\
\text { TTGTTGGTGGTGACTTTGGA }\end{array}$ & $\begin{array}{l}59.81 \\
59.98\end{array}$ & 203 \\
\hline hsa-mir-1228 & $\begin{array}{l}\text { GCCAATGACTGTGGGGACTA } \\
\text { GGCAGGCGAAGTAATTCAGA }\end{array}$ & $\begin{array}{l}60.92 \\
60.35\end{array}$ & 158 \\
\hline hsa-mir-4532 & $\begin{array}{l}\text { CCCACCCCTTGCCTATAATC } \\
\text { TTCAGGGTTGCTCTGTTCAA }\end{array}$ & $\begin{array}{l}60.52 \\
59.41\end{array}$ & 129 \\
\hline hsa-mir-6127 & $\begin{array}{l}\text { GATGGAGAAAGTGGGGTTCA } \\
\text { ACCAGAGCGGAAGGAATCTT }\end{array}$ & $\begin{array}{l}59.90 \\
60.21\end{array}$ & 211 \\
\hline hsa-mir-6852 & $\begin{array}{l}\text { TGCCTGGACAGTGTAATGGA } \\
\text { GTTCTTGGCATTTTGGGAGA }\end{array}$ & $\begin{array}{l}60.11 \\
60.05\end{array}$ & 188 \\
\hline
\end{tabular}




\section{Expressional Analysis}

100ng of the cDNAs from HB patient and control samples were used as the template for PCR. The PCR was programmed as; Initial denaturation at $95^{\circ} \mathrm{C}$ for 3 minutes followed by 35 cycles of denaturation $94^{\circ} \mathrm{C}$ for 30 seconds, annealing at $60^{\circ} \mathrm{C}$ for 30 seconds and extension at $72^{\circ} \mathrm{C}$ for 35 seconds and a final elongation step at $72^{\circ} \mathrm{C}$ for 10 minutes. The PCR products were separated run and checked on $2.0 \%(\mathrm{w} / \mathrm{v})$ agarose gel with 100bp DNA ladder. The gel images were saved.

\section{Results and discussion}

The differentially expressed RNAs are always the prime source of significant findings $[14,15]$. In this study, a total of 15 significant miRNAs, representing a valid expressional response to $\mathrm{HBV}$, were identified through a detail literature survey and subjected to the RT-PCR expressional studies in HB patient from Quetta, Pakistan. These fifteen (15) miRNAs were; hsa-mir20, 21, 30, 99, 122, 141, 190, 200, 223, 320, 574, 1228, 4532, 6127 and 6852. The invasion of the HBV in the host cell triggers an alteration in the expression of the host cell's miRNAs. This alteration of host cell's miRNAs may be either up or down regulation. These differentially expressed miRNAs are the important source to unravel the precise mechanism between miRNA and HBV. And it will also lead to developing new molecular techniques for the novel diagnosis and therapy of HB.

\section{Upregulated miRNAs}

The cDNAs synthesized from the total RNAs of HB patients and healthy persons were subjected to the expressional analysis of selected 15 miRNAs and an internal control GAPDH. The eight out of fifteen miRNAs showed upregulated expression in HB patients from Quetta-Pakistan (Figure
1). These eight miRNAs are hsa-mir-20, 21 , 30, 99, 141, 574, 4532 and 6852.

The miR-20 is an important member of the miR-17 microRNA precursor family. This family is reported as a key player causing a wide-range of various malignancies and some researcher referred to as oncomirs [16, 17]. Based on the Chang et al. [18] and Zhang et al., [19] reports the miR-20 is an integrated component of the molecular pathways that regulate tumor development and tumor maintenance and upregulation of the miR-20a, in different models such as, human cancers and cell culture systems showed an ability to regulate a number of cellular processes that favor malignant transformation.

In this study, the hsa-mir-20 is also observed up-regulated in HB patients from Quetta, Pakistan and it confirmed that the mir-20 is causing hepatocellular carcinoma or chronic hepatitis in the Quetta's HB patients. So, by developing an approach to downregulate the miR-20 in HB patient would be a good initiative to suppress the growth of hepatocellular carcinoma or chronic hepatitis [20].

The mir-21 is one of the first mammalian microRNAs identified and reported as the most frequently upregulated miRNAs in solid tumors [21]. The mir-21 is also reported for additional roles in cardiovascular and pulmonary diseases, including cardiac and pulmonary fibrosis as well as myocardial infarction by regulating various immunological and developmental processes [22]. A very prominent upregulation for the hsa-mir-21 is observed in this study (Figure 1). Due to the key functions of its target proteins in different signaling pathways, miR-21 has become an attractive candidate for genetic and pharmacological modulation in various disease conditions. 


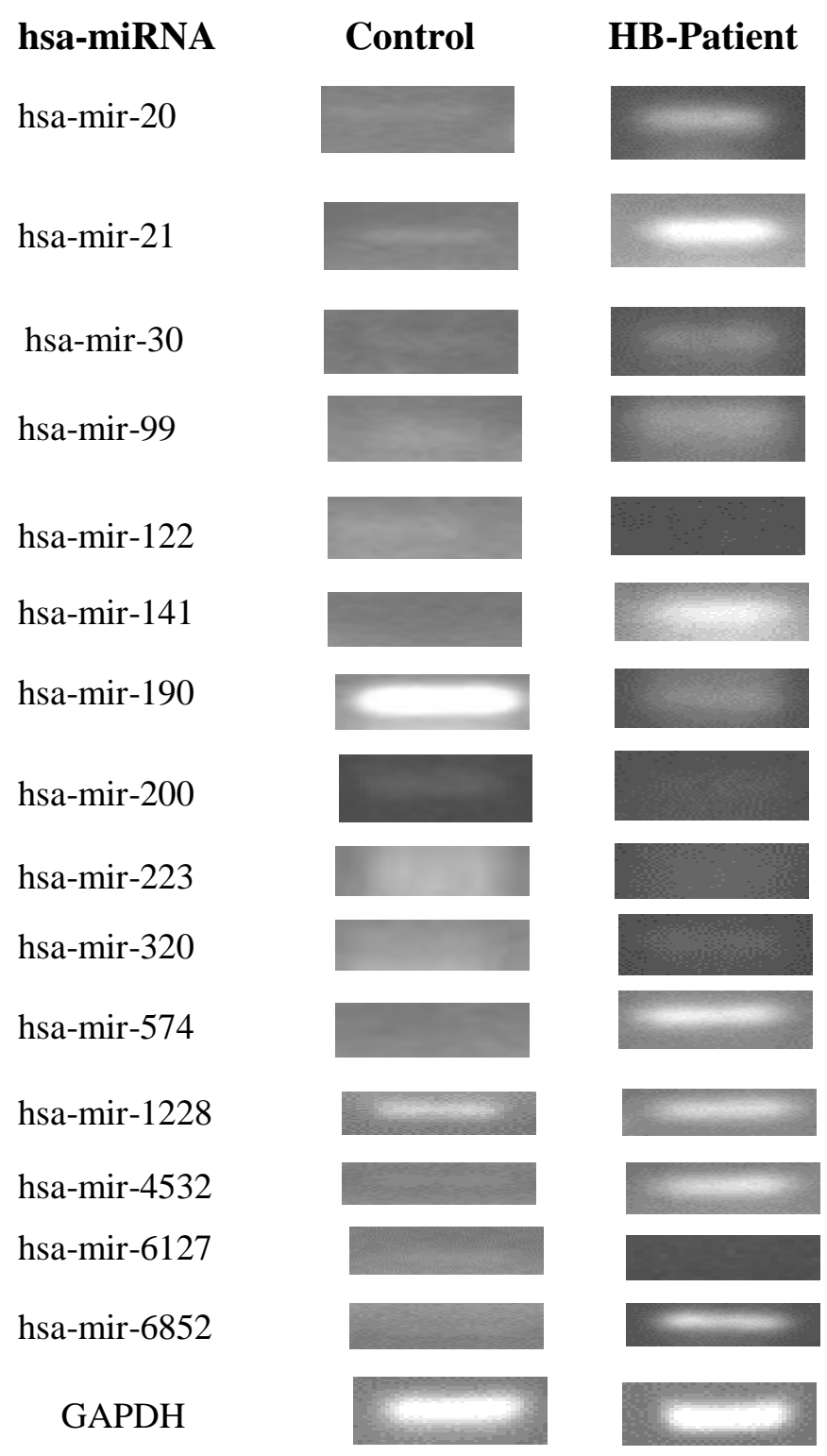

Figure 1. Experimental analysis of the selected human miRNAs in hepatitis B patients from Quetta, Pakistan by RT-PCR. The fifteen human significant miRNAs, demonstrating strong expressional response to $\mathrm{HBV}$, identified through literature survey and a GAPDH-as internal control gene, were subjected to the expression analysis through RT-PCR. The eight miRNAs; hsa-mir-20, 21, 30, 99, 141, 574, 4532 and 6852 showed upregulation, whereas, the six miRNAs; hsa-mir-122, 190, 200, 223, 320, and 6127 showed downregulation in HB-patient. The one miRNA; 1228 is observed with equal expression in both patient and healthy person.

The miR-30s and 99 are reported to function as a tumor suppressor by targeting the oncogene and thus would be a new therapeutic tool to control and cure the cancer, including the hepatocellular carcinoma or chronic hepatitis in HB patients [23, 24]. The upregulation of hsamir-30 and 99 in HB patients from Quetta, 
in this study, validated its role and importance in the hepatitis biology.

miR-141 is reported with impact on tumor prognosis by regulating redox reaction in the cell. It is observed for a crosstalk between oxidative stress and tumor genesis [25]. The mir-141 miRNA along with the hsa-mir-574, 4532 and 6852 were also found overexpressed in the HB Quetta's patients. On the basis of overexpression, these miRNAs can be used as a molecular predictive marker for the early diagnosis of HB.

\section{Down-regulated miRNAs}

Off 15, six miRNAs are down-regulated in HB-patient of Quetta, Pakistan (Figure 1). These miRNAs are; hsa-mir-122, 190, 200, 223, 320, and 6127. The miR-122 is a conserved liver-specific miRNA that plays significant role in the metabolism and metastasis in liver biology and disease [26]. Recently, Luna et al. [27], conduct a research on Argonaute cross-linking immunoprecipitation sequencing in miR-122 knockout and control mouse livers, as well as in matched human hepatocellular carcinoma (HCC) and benign liver tissue to identify miRNA target sites transcriptomewide in two species and showed molecular consequences of miR-122 downregulation in hepatocellular carcinoma. The downregulation of the same miRNA in the Quetta's HB patients confirming it.

Simmons [28] reported that miRNAs miR$8 / 200$ and miR-190 regulate Glucosylceramide synthase, a key enzyme in lipid metabolism and obesity in human and Drosophila cells. The hsa-mir-199 and 200 are found down expressed in Quetta's HB patients and this finding is in contrast with the findings of the Cramer et al. [29] who reported that miR-190 is upregulated in Epstein-Barr Virus type I latency. This suggests a different expression behavior for mir-190 in Quetta's HB patients.
Recently, Dong et al. [30] demonstrated that miR-223 could suppress cell growth and promote apoptosis in HepG2 and Bel-7402 HCC cell lines. The downregulation of the same miRNA in the Quetta's HB patients confirms a link between this miRNA in liver cancer.

Very recently, Wang et al. [31] reported that the high expression of hsa-miR-320 indicated negative prognosis and high risk of metastasis in ovarian malignancy. Similarly, Xaio et al. [32] reported the observation of upregulation for the hsa-mir-6127 in gastric stromal tumor tissues. Whereas, the hsa-mir6127 is observed with down-expression in this study, suggesting different expression pattern in different organ diseases.

\section{Equal expressed miRNA}

Off 15 selected human miRNAs for the differential expression analysis in the HB patients from Quetta, Pakistan, only one miRNA, i.e, hsa-mir-1228 is observed with equal expression, means having no difference in the expression in both patient and healthy person (Fig-1). $\mathrm{Hu}$ et al. [33] subjected eleven candidate miRNAs (miR1225-3p, miR-1228, miR-30d, miR-939, miR-940, miR-188-5p, miR-134, miR-16, miR-223, let-7a, and RNU6B) to select the most stable endogenous control, as a housekeeping gene across eight cancer types and three controls for the quantification of circulating microRNAs and found that only miR-1228 is a promising stable endogenous control. The same finding of equal expression for hsa-mir-1228 in HB patient and healthy person, in this study, strongly confirms that mir-1228 is a best internal control for the differential expressional studies of miRNAs in the HB patients.

\section{Conclusion}

To the best of authors' knowledge, this is the first study reporting miRNAs expressional behavior in the hepatitis B patients of Quetta, Pakistan. The findings of 
the eight upregulated, six downregulated and one with equal expression in HB patient and healthy person would serve a baseline data to develop the molecular markers for the early diagnosis and therapeutics tools that are based on small and tiny miRNAs.

\section{Author's Contributions}

Conceived and designed the experiments: MYK Barozai \& A Sajjad, Performed the Experiments: Shahjahan, $M$ Din \& $H$ Achakzai, Analysed the data: MYK Barozai, Shahjahan, M Din \& H Achakzai, Contributed reagents/ materials/ analysis tools: MYK Barozai, Wrote the paper: MYK Barozai, M Din \& A Sajjad

\section{References}

1. Bibi F, Barozai MYK \& Din M (2017). Bioinformatics profiling and characterization of potential microRNAs and their targets in the genus Coffea. Turkish Journal of Agriculture and Forestry 41(3): 191-200.

2. Lewis BP, Burge CB, Bartel DP. Conserved seed pairing, often flanked by adenosines, indicates that thousands of human genes are microRNA targets. Cell. 005; 120:15-20. doi: 10.1016/j.cell.2004.12.035.

3. Barozai MYK \& Din M (2017). Initial screening of plant most conserved MicroRNAs targeting infectious viruses: HBV and HCV. In Applied Sciences and Technology (IBCAST), 2017 14th International Bhurban Conference on (pp. 192-196). IEEE.

4. Din M, Barozai MYK \& Baloch IA (2016). Profiling and annotation of microRNAs and their putative target genes in chilli (Capsicum annuum L.) using ESTs. Gene Reports 5: 62-69.

5. Gul Z, Barozai MYK \& Din M (2017). In-silico based identification and functional analyses of miRNAs and their targets in Cowpea (Vigna unguiculata L.). Aims Genetics 4(2): 138-165.
6. Ganem D \& Prince AM (2004). Hepatitis B virus infection-natural history and clinical consequences. $N$ Engl J Med 350: 1118-1129

7. Wieland SF, Spangenberg HC, Thimme R, Purcell RH, Chisari FV (2004). Expansion and contraction of the hepatitis B virus transcriptional template in infected chimpanzees. Proc Natl Acad Sci USA 101: 2129-2134

8. Chan K, Eric B, David SS, William SK \& Scott KD (2008). Prolonged hemophagocytic lymphohistiocytosis syndrome as an initial presentation of Hodgkin lymphoma: a case report. J. of Med. Case Reports 2: 367 doi:10.1186/1752-1947.

9. Lamontagne J, Steel LF, \& Bouchard MJ (2015). Hepatitis B virus and microRNAs: Complex interactions affecting hepatitis B virus replication and hepatitis B virus-associated diseases. World journal of gastroenterology 21(24): 7375.

10. $\mathrm{Xu} \mathrm{J}, \mathrm{Wu} \mathrm{C}$, Che $\mathrm{X}$, Wang L, Yu D, Zhang T, Huang L, Li H, Tan W, Wang $\mathrm{C} \&$ Lin D (2011). Circulating MicroRNAs, miR-21, miR-122, and miR-223, in patients with hepatocellular carcinoma or chronic hepatitis. Molecular carcinogenesis 50 (2): 136142.

11. Tan Y, Ge G, Pan T, Wen D, Chen L, Yu X, Zhou X \& Gan J (2014). A serum microRNA panel as potential biomarkers for hepatocellular carcinoma related with hepatitis B virus. PloS one 9(9): p.e107986.

12. Akamatsu S, Hayes CN, Tsuge M, Miki D, Akiyama R, Abe H, Ochi H, Hiraga N, Imamura M, Takahashi S \& Aikata $H$ (2015). Differences in serum microRNA profiles in hepatitis B and C virus infection. Journal of Infection 70(3): 273-287. 
13. Barber RD, Harmer DW, Coleman RA, \& Clark BJ (2005). GAPDH as a housekeeping gene: analysis of GAPDH mRNA expression in a panel of 72 human tissues. Physiological genomics 21(3): 389-395.

14. Barozai MYK \& Husnain T (2012). Identification of biotic and abiotic stress up-regulated ESTs in Gossypium arboreum. Molecular biology reports 39(2): 1011-1018.

15. Barozai MYK \& Wahid HA (2012). Insilico identification and characterization of cumulative abiotic stress responding genes in Potato (Solanum tuberosum L.). Pak. J. Bot 44: 57-69.

16. Fu H, Tie Y, Xu C, Zhang Z, Zhu J, Shi $Y$ \& Zheng X (2005). Identification of human fetal liver miRNAs by a novel method. FEBS letters 579(17): 38493854.

17. Lui WO, Pourmand N, Patterson BK, $\&$ Fire A (2007). Patterns of known and novel small RNAs in human cervical cancer. Cancer research 67(13): 60316043.

18. Chang Y, Liu C, Yang J, Liu G, Feng F, Tang J, et al. (2013). MiR-20a triggers metastasis of gallbladder carcinoma. $J$ Hepatol 59: 518-527

19. Zhang JX, Song W, Chen ZH, Wei JH, Liao YJ, Lei J, et al. (2013) Prognostic and predictive value of a microRNA signature in stage II colon cancer: a microRNA expression analysis. Lancet Oncol. 14: 1295-1306.

20. Zhao S, Yao D, Chen J, Ding N \& Ren F (2015). MiR-20a Promotes Cervical Cancer Proliferation and Metastasis In Vitro and In Vivo. PLOS ONE 10(3): e0120905.

https://doi.org/10.1371/journal.pone.012 0905

21. Iorio MV, Ferracin M, Liu CG, Veronese A, Spizzo R, Sabbioni S,
Magri E, Pedriali M, Fabbri M, Campiglio M, Ménard S, Palazzo JP, Rosenberg A, Musiani P, Volinia S, Nenci I, Calin GA, Querzoli P, Negrini M \& Croce CM (2005). MicroRNA gene expression deregulation in human breast cancer. Cancer Research 65 (16): 7065-70.

22. Kumarswamy R, Volkmann I \& Thum $T$ (2011). Regulation and function of miRNA-21 in health and disease. RNA biology 8(5): 706-713.

23. Zhao JJ, Lin J, Zhu D, Wang X, Brooks D, Chen M \& Tai YT (2014). miR-30$5 p$ functions as a tumor suppressor and novel therapeutic tool by targeting the oncogenic $\quad \mathrm{Wnt} / \beta$-catenin/BCL9 pathway. Cancer research 74(6) 18011813

24. Sun D, Lee YS, Malhotra A, Kim HK, Matecic M, Evans C, Jensen RV, Moskaluk CA \& Dutta A (2011). miR99 family of MicroRNAs suppresses the expression of prostate-specific antigen and prostate cancer cell proliferation. Cancer research 71(4): 1313-1324.

25. Mateescu B, Batista L, Cardon M, Gruosso T, De Feraudy Y, Mariani O, Nicolas A, Meyniel JP, Cottu P, SastreGarau X \& Mechta-Grigoriou F (2011). miR-141 and miR-200a act on ovarian tumorigenesis by controlling oxidative stress response. Nature medicine 17(12): 1627-1635.

26. Hsu SH, Wang B, Kota J, Yu J, Costinean S, Kutay H, Yu L, Bai S, La Perle K, Chivukula RR \& Mao H (2012). Essential metabolic, antiinflammatory, and anti-tumorigenic functions of miR-122 in liver. The Journal of clinical investigation 122(8): 2871-2883.

27. Luna JM, Barajas JM, Teng KY, Sun HL, Moore MJ, Rice CM, Darnell RB \& Ghoshal K (2017). Argonaute CLIP Defines a Deregulated miR-122-Bound 
Transcriptome that Correlates with Patient Survival in Human Liver Cancer. Molecular Cell 3 67(3): 400410.e7. doi: 10.1016/j.molcel.2017.06.025

28. Simmons D (2016). Investigating the role of mir-190, mir-200, and mir- 8 inhibition of the GCS protein in HeLa cells and Drosophila melanogaster. Honors Theses AY 15/16. 77. http://repository.uwyo.edu/honors_these s_15-16/77

29. Cramer EM, Shao Y, Wang Y \& Yuan $Y$ (2014). miR-190 is upregulated in Epstein-Barr Virus type I latency and modulates cellular mRNAs involved in cell survival and viral reactivation. Virology 464: 184-195.

30. Dong Z, Qi R, Guo X, Zhao X, Li Y, Zeng Z, Bai W, Chang X, Hao L, Chen Y \& Lou M (2017). MiR-223 modulates hepatocellular carcinoma cell proliferation through promoting apoptosis via the Rab1-mediated mTOR activation. Biochemical and biophysical research communications 483(1): 630637.

31. Wang W, Yang J, Xiang YY, Pi J \& Bian J (2017). Overexpression of Hsa-miR-320 Is Associated With Invasion and Metastasis of Ovarian Cancer. Journal of Cellular Biochemistry doi 10.1002/jcb.26009

32. Xiao J, Wang QX \& Zhu YQ (2015). Altered expression profile of microRNAs in gastric stromal tumor. Journal of Huazhong University of Science and Technology 35(6): 842850.

33. Hu J, Wang Z, Liao BY, Yu L, Gao X, Lu S, Wang S, Dai Z, Zhang X, Chen Q \& Qiu SJ (2014). Human miR-1228 as a stable endogenous control for the quantification of circulating microRNAs in cancer patients. International journal of cancer 135(5): 1187-1194. 